\title{
ANALISIS KERUANGAN TERHADAP PERUBAHAN DAN PERSEBARAN PERMUKIMAN KUMUH DI KECAMATAN BANJARSARI KOTA SURAKARTA TAHUN $2001-2005$
}

\author{
Dahroni \\ Fakultas Geografi Universitas Muhammadiyah Surakarta \\ J1. A. Yani Pabelan Kartasura Tromol Pos I Surakarta 57102, Telp. (0271) 717417 \\ Psw. 151-153, Fax. (0271) 7155448 \\ E-mail: dahroni@ums.ac.id
}

\begin{abstract}
Qince the year 1998 up to the mid of 2005, in the district ofBanjarsari, there happened an increasing amount of slum areas which might endanger the environmental balance. This research aims at (1) identifying the shift of distribution pattern from the settlement diffusion in the district of Banjarsari Surakarta in the year 2001-2005. (2) Identifying the alteration form of the unoccupied land into slum areas in the district of Banjarsari Surakarta. (3) Identifying the characteristics of slum area dwellers in the district of Banjarsari Surakarta. This research uses the survey method, secondary data analysis and map analysis. The data ar alysis used is tlie closest neighbor analysis, table of frequency, crossed tables and descrip ave analysis. The result shows that (1) the distribution pattern of the slum areas appeared in the district ofBanjarsari in the year 2001 is the random distribution pattern while the one in 2005 is the dissemination pattern. Such pattern indicates the grc wing amount and interraction with the means of transportation and economic condition in those slum areas. (3) The lands which are altered into slum areas in the district of Banjarsari during 2001-2005 take place in the unoccupied areas owned by the state.(3) The distribution of age among the slum area inhabitants is around 41-61 years of age (49\%) while th biggest amount is the new arrivals (57\%). The region of Sub province Sragen has the bigges percentage in the distribution of the city inhabitants origin in the district of Banjarsari. Regionally, the inhabitants who come from the binterland of Surakarta or ex Surakarta residency took the amount lof $73.68 \%$. The bighest percentage of educational level of the slum area inhabitants in the district of Banjarsari is the uneducated residents or those from low education level (55\%). Most of the respondents occupations of the slum area dwellers in Banjarsari are in the informal sectors (82\%) The number of family member in the district of Banjarsari is around $l-<5(52 \%)$. The total family incone of the slum area inbabitants which has the highest percentage are about R. 150.000-, R. 716.666 (60\%). The orientation toward living in the slum areas which has the biggestpercentage is a matter of distance to the workplace $(72 \%)$. The reaction toward condemnation which has the biggest percentage is taken for granted (73\%).
\end{abstract}

Keywords: distribution, Dwellers/inhabitants, shum areas

\section{PENDAHULUAN}

Salah satu objek studi kependudukan yang cukup menarik untuk dipelajari saat ini adalah menyangkut keadaan permukiman penduduk. Permukiman tidak akan berhenti sebagai sumber masalah dalam sejarah kehidupan manusia. Krisis ekonomi yang melanda Indonesia semenjak tahun 1998 telah menjadikan perekonomian negara menjadi terpuruk dan berimbas pada penurunan kesejahteraan rakyat. Hampir seluruh wilayah di Indonesia merasakan dampak dari terjadinya krisis ekonomi tersebut, tidak terkecuali di wilayah Kecamatan Banjarsari Kota Surakarta. Keca- 
matan Banjarsari memiliki luas area 1.481,1 ha atau sekitar $14,811 \mathrm{~km}^{2}$. Sampai tahun 2005 jumlah penduduk yang tercatat sebanyak 162.256 jiwa (sumber : Monografi Kecamatan, 2005). Hampir keseluruhan wilayah Kecamatan Banjarsari memiliki topografi datar dengan kemiringan lereng $<2 \%$ dengan kedalaman air tanah yang relatif dangkal. Keadaan tersebut menyebabkan Kecamatan Banjarsari merupakan lokasi yang ideal untuk permukiman.

Selama tahun 1998 - pertengahan 2005 berdasarkan pengamatan penulis telah terjadi peningkatan jumlah keluarga miskin atau keluarga pra sejahtera. Keadaan tersebut salah satunya diindikasikan dengan semakin meningkatnya jumlah permukiman - permukiman kumuh yang tersebar di beberapa titik dalam wilayah Kecamatan Banjarsari seperti kedua sisi wilayah sempadan Sungai Pepe dan Sungai Anyar yang memanjang dari Kelurahan Sumber sampai batas dengan Kecamatan Jebres, wilayah pinggir jaringan rel kereta api serta lokasilokasi pondok boro yang ada di Kelurahan Sumber dan Nusukan.

Penambahan jumlah permukiman kumuh di wilayah tersebut jelas akan menimbulkan situasi yang membahayakan bagi lingkungan. Pada lokasi di sempadan sungai misalnya, tekanan penduduk yang terlalu berlebihan berupa munculnya bangunan permukiman dapat menimbulkan bahaya longsor pada tanggul sungai yang ada sehingga dikhawatirkan akan dapat menimbulkan bahaya banjir yang dapat menimbulkan korban manusia. Namun pada sisi yang lain kebutuhan permukiman yang semakin mendesak bagi penduduk yang ada serta peraturan pemerintah yang tidak tegas menyebabkan tindakan penggusuran dari pihak pemerintah dapat me- nimbulkan gejolak sosial yang juga sangat berbahaya. Salah satu cara yang dilakukan Pemerintah Daerah pada saat ini adalah melakukan pengawasan terhadap peningkatan jumlah dan persebaran lingkungan kumuh di wilayah Kecamatan Banjarsari.

Tujuan Penelitian ini adalah: (1) Mengetahui perubahan pola distribusi dari penjalaran (diffusi) permukiman di Kecamatan Banjarsari Kota Surakarta tahun 2001 - 2005. (2) Mengetahui bentuk perubahan penggunaan lahan yang tergantikan untuk kawasan permukiman kumuh di Kecamatan Banjarsari Kota Surakarta. (3) Mengetahui karakteristik dari penghuni permukiman kumuh di Kecamatan Banjarsari Kota Surakarta.

\section{METODE PENELITIAN}

Metode penelitian yang digunakan dalam penelitian ini adalah metode survai, analisis data sekunder dan analisis peta. Metode survai artinya informasi diperoleh langsung dari responden penghuni kawasan kumuh dengan menggunakan kuisioner serta pengecekan daerah - daerah yang berubah menjadi permukiman kumuh. Unit analisis data sekunder yang digunakan adalah data yang mencakup tentang kependudukan yaitu kawasan kumuh yang ada selama tahun 2001 - 2005 di Kecamatan Banjarsari Kota Surakarta.

Data yang dibutuhkan: (1) data statistik kependudukan di Kecamatan Banjarsari Kota Surakarta tahun 2001 2005. (2) data jumlah dan persebaran permukiman kumuh di Kecamatan Banjarsari Tahun 2001 - 2005. (3) Peta Administratif Kecamatan Banjarsari. (4) Peta persebaran permukiman kumuh di Kecamatan Banjarsari Kota Surakarta. 
Analisis data untuk menjawab tujuan I dilakukan melalui pemetaan dengan mengunakan bantuan SIG. Dalam Sistem Informasi Geografi data tersimpan dalam format digital, jumlah data yang besar dapat disimpan dan dipanggil kembali secara cepat dengan basis data spasial. Basis data spasial terbagi menjadi atas dua bagian, yaitu sub himpunan data grafis (peta digital) dan sub himpunan data atribut.

Komponen Sistem Informasi Geografi terdiri dari perangkat keras dan lunak. Perangkat keras yang digunakan terdiri atas seperangkat komputer yang berfungsi untuk menyimpan, menampilkan teks dan interaksi dengan penggunaan, serta meja digitizer yang berfungsi untuk mengubah data analog mrnjadi data dalam format digital. Plotter dan printer digunakan untuk menayangkan hasil pemrosesan data yang berupa peta. Perangkat lunak Arc info dapat dikelompokkan ke dalam beberapa modul antara lain Arcedit, Arcplot, Arc View, Overlay, data Conversion, Network, dan Tables/info. Perangkat Arc info termasuk perangkat lunak yang berbasis Vektor. Perangkat lunak berbasis vector adalah perangkat lunak yang data grafisnya disimpan dan dimanipulasi serta dianalisis dalam bentuk format vector. Data vector adalah data yang tersusun atas segmensegmen yang disimpan melalui persamaan matematik tertentu.

Adapun langkah-langkah dalam pengolahan data dengan SIG ada beberapa tahap yaitu :

1. Pemasukan data

2. Manipulasi dan analisis data

3. Keluaran /hasil

Data masukan yang digunakan untuk pengolahan dan pemrosesan dengan SIG terdiri atas dua macam yaitu data grafis (spasial) dan data atribut (tabular), kumpulan data grafis dan data atribut ini disebut sebagai basis data (database) yang meliputi posisinya dipermukaan bumi dan atribut dari kenampakan tersebut yang tersimpan dalam bentuk titik, garis, area, piksel, ataupun grid.

Setelah dilakukan langkah pemetaan data maka langkah selanjutnya yang dilakukan adalah menganalisis aspek geografis dari peta yang dihasilkan, meliputi :

1. Menganalisis peta persebaran jumlah permukiman kumuh untuk mengetahui jumlah, luas dan persebaran permukiman kumuh yang ada.

2. Menganalisis pola persebaran permukiman kumuh dengan menggunakan analisis tetangga terdekat.

Analisis seperti ini memerlukan data tentang jarak antara satu objek yang paling dekat yaitu objek tetangganya yang terdekat. Sehubungan dengan hal ini tiap objek dianggap sebagai sebuah titik dalam ruang.

Dalam menggunakan analisis tetangga terdekat harus diperhatikan beberapa langkah sebagai berikut : (a) menentukan batas wilayah yang akan diselidiki ; (b) mengubah pola persebaran objek seperti yang terdapat dalam peta topografi menjadi pola persebaran acak ; (c) memberikan nomor urut bagi tiap titik untuk mempermudah cara menganalisisnya; (d) mengukur jarak terdekat yaitu jarak pada garis lurus antara satu titik dengan titik yang lain yang merupakan tetangga terdekatnya dan catatlah ukuran jarak tersebut ; (e) menghitung besar parameter tetangga terdekat $(\mathrm{T})$ dengan menggunakan formula: 


$$
\begin{aligned}
T=\frac{\overline{j u}}{j h} & \\
\mathrm{~T} \quad & \text { Indeks penyebaran tetangga } \\
\overline{j u}= & \text { Jerdekat } \\
& \text { antara satu titik dengan titik } \\
& \text { tetangganya yang terdekat } \\
= & \text { Jarak rata-rata yang diperoleh } \\
& \text { andaikata semua titik mem- } \\
& \text { punyai pola random } \\
= & \frac{1}{2 \sqrt{P}} \\
= & \text { Kepadatan titik dalam tiap ki- } \\
& \text { lometer persegi yaitu jumlah } \\
& \text { titik (N) dibagi dengan luas } \\
& \text { wilayah dalam kilometer persegi } \\
\mathrm{P} \quad & \text { A) sehingga menjadi } \frac{N}{A} .
\end{aligned}
$$

Untuk memperoleh $\bar{j} u$ digunakan cara dengan menjumlahkan semua jarak tetangga terdekat dan kemudian dibagi dengan jumlah titik yang ada. Adapun variabel untuk menentukan suatu lokasi permukiman dapat dikategorikan permukiman kumuh atau bukan dapat dilakukan melalui survai terrestrial

Untuk menjawab tujuan penelitian II dan III digunakan analisis tabel frekuensi. Menurut Masri Singarimbun dan Sofian Efendi (1981), tabel frekuensi digunakan untuk mengetahui karakteristik dan distribusi satu variabel. Di samping itu teknik analisis ini walaupun sederhana tetapi memiliki kemampuan besar untuk mengungkapkan yang hendak diteliti.
HASIL PENELITIAN DAN PEMBAHASAN

Hasil penelitian menunjukkan : (1) Melalui perhitungan dengan mendasarkan pada teori yang dikemukakan Bintarto dan Surastopo Hadisumarno (1979) maka nilai yang diperoleh dari pola persebaran permukiman kumuh di Kecamatan Banjarsari tahun 2001 menunjukkan pola persebaran acak, sebab nilai 0,738 lebih mendekati nilai $\mathrm{T}=1$ yang merupakan nilai syarat apabila suatu pola persebaran dianggap sebagai acak. Nilai yang diperoleh dari pola persebaran permukiman kumuh di Kecamatan Banjarsari tahun 2005 menunjukkan pola persebaran mengelompok, sebab nilai 0,448 lebih mendekati nilai $\mathrm{T}=0$ yang merupakan nilai syarat apabila suatu pola persebaran dianggap sebagai mengelompok.

(2) lahan yang peruntukannya tergantikan untuk kawasan permukiman kumuh di Kecamatan Banjarsari Kota Surakarta selama tahun 2001 - 2005 terjadi pada lahan - lahan kosong milik negara terutama pada Bantaran Sungai Pepe dan Sungai Anyar, depan Terminal Induk Bus Tirtonadi, sepanjang Rel Kereta Api Stasiun Balapan yang menuju ke arah timur maupun di kawasan Monumen Banjarsari yang menjadi kawasan perdagangan sekaligus permukiman. Berdasarkan perhitungan luas lahan yang tergantikan untuk kawasan permukiman kumuh selama tahun 2001 - 2005 dengan menggunakan bantuan Sistem Informasi Geografis (SIG) dapat diperoleh luas sebesar 25,639 hektar. Dalam kurun waktu selama 5 tahun, perubahan lahan tersebut dapat dikatakan cukup luas terutama mengingat luas keseluruhan wilayah Kota Surakarta yang hanya mencapai 1.481 hektar. 
(3) Distribusi umur penghuni permukiman kumuh di Kecamatan Banjarsari dengan persentase terbesar adalah berusia 41 - 61 tahun sebesar 49\% diikuti responden berusia $<41$ tahun sebesar $41 \%$. Dengan mengacu pada ketentuan usia produktif adalah $15-64$ tahun, maka hampir 91\% responden termasuk dalam usia produktif; Status kependudukan penghuni permukiman kumuh di Kecamatan Banjarsari dengan persentase terbesar adalah penduduk pendatang sebesar 57\%; Daerah asal penghuni permukiman kumuh di Kecamatan Banjarsari dengan persentase terbesar $(22,81 \%)$ berasal dari wilayah Kabupaten Sragen. Secara kewilayahan, daerah asal penghuni permukiman kumuh di Kecamatan Banjarsari didominasi mereka yang berasal dari hinterland (daerah penyangga) Kota Surakarta atau eks wilayah Karesidenan Surakarta yaitu sebesar 73,68\%; Tingkat pendidikan penghuni permukiman kumuh di Kecamatan Banjarsari dengan persentase terbesar adalah tidak sekolah - tidak tamat SLTP (kategori tingkat pendidikan rendah) sebesar 55\%; Pekerjaan yang dimiliki responden penghuni permukiman kumuh di Kecamatan Banjarsari dengan persentase terbesar adalah pada sektor informal, yaitu sebesar $82 \%$. Pekerjaan yang disebutkan oleh responden (seperti : pedagang, pemulung, tukang becak, buruh bangunan, buruh angkut, penjual makanan maupun jasa penitipan) merupakan pekerjaan yang tidak memerlukan pendidikan ataupun keterampilan khusus; Jumlah anggota keluarga penghuni permukiman kumuh di Kecamatan Banjarsari dengan persentase terbesar adalah $1-<5$ orang, yaitu sebesar $52 \%$; Pendapatan total keluarga penghuni permukiman kumuh di Kecamatan Banjarsari dengan persentase terbesar adalah Rp. 150.000 - < Rp.716.666, yaitu sebesar $60 \%$. Tingkat pendapatan ini dikategorikan pendapatan yang rendah; Orientasi bermukim penghuni permukiman kumuh di Kecamatan Banjarsari dengan persentase terbesar adalah dekat dengan tempat kerja, yaitu sebesar 72\%. Alasan alasan yang dikemukakan oleh responden umumnya mengacu pada dua hal, yaitu alasan yang bersifat ekonomis dan aksesibilitis; Reaksi apabila terjadi penggusuran yang dikemukakan responden penghuni permukiman kumuh di Kecamatan Banjarsari dengan persentase terbesar adalah menerima dengan pasrah, yaitu sebesar $73 \%$.

Peningkatan kebutuhan akan lahan, khususnya di daerah perkotaan semakin nampak terutama lahan sebagai wadah untuk menampung kegiatan manusia maupun sebagai wadah untuk bermukim. Peningkatan jumlah penduduk di perkotaan tidak hanya dipengaruihi oleh pertumbuhan penduduk alami semata, tetapi Juga dipengaruhi oleh banyaknya pendatang baru baik dari daerah pedesaan maupun dari daerah perkotaan di sekitarnya (Yunus:2001).

Pesatnya perkembangan kota menjadi salah satu daya tarik bagi penduduk di daerah hinterland, untuk berbondongbondong bermigrasi masuk ke daerah perkotaan, hal ini akan berakibat terkonsentrasinya penduduk di sekitar zona inti kota (core zone) atau di zone selaput inti kota, seiring dengan pertumbuhan penduduk yang disebabkan oleh faktor alamiah maupun adanya migrasi penduduk ke daerah perkotaan, permintaan akan lahan untuk permukiman juga semakin meningkat, sementara luas lahan kota secara administratif tetap, konsekuensi ekonomis yang harus disandang adalah harga akan lahan semakin meningkat, akibat yang muncul 
terutama bagi migran dan juga penduduk kota yang status ekonominya lemah, adalah rendahnya kemampuan untuk memiliki rumah.

Dampak yang terjadi selanjutnya adalah terjadinya pemadatan bangunan (densifikasi) permukiman, yang berakibat menurunnya kualitas permukiman, dengan demikian di daerah perkotaan akan timbul daerah-daerah permukiman yang kurang layak huni yang sangat padat, dan hal ini akan membawa suatu akibat pada kondisi lingkungan permukiman yang buruk, yang selanjutnya disebut sebagai daerah kumuh (slum area).

Di Indonesia permukiman kumuh hingga tahun 2000 mencapai 47 ribu hektar. Di kota-kota besar pada tahun 2002 meliputi: Jakarta dengan luasan 4.481,6 hektar dan dihuni oleh 2,4 juta jiwa atau sekitar $20 \%$ dari seluruh penduduknya 4,296 dari luas permukiman keseluruhan, Bandung meliputi 402 hektar dihuni oleh 205.465 jiwa atau $20 \%$, Surabaya meliputi luasan 2.196 hektar dihuni oleh 900.870 jiwa (25\%). (http: \www.Kimpraswil.go.id/ humas/infoterkini/ ppw091002.htm).

Beberapa penelitian tentang studi kualitas permukiman kota atau tentang daerah kumuh antara lain: Clinord (1978), mengadakan penelitian di kota-kota besar di India khususnya di kota-kota Calcuta, Bombay, New Delhi, Madras, Madurai dan Ahmebadad, mengindikasikan bahwa kekumuhan di kota-kota besar di India tidak terlepas dari pengaruh pertambahan penduduk terutama kepadatannya, sebagai akibat urbanisasi, kemiskinan kebudayaan dan kemauan politik.

Laquian (1971) mengadakan pene- litian di Manila dan memberikan bobot perhatian yang lebih besar pada aspekaspek politik di dalam menangani permasalahan permukiman kumuh di Manila. Gilberi dan Gugler (1996) didasarkan atas penelitian di Amerika latin dan Afrika dengan memberikan konsentrasi pada aspek urbanisasi dan kemiskinan.

Sutanto (1985), mengemukakan bahwa permukiman kumuh dapat diidentifikasi dari foto udara berdasarkan faktor fisiknya, antara lain: ukuran rumah kecil, kepadatan rumah tinggi, atap dengan rona tidak seragam. Atas dasar morfologinya pada foto udara, permukiman kumuh dapat dibedakan menjadi enam kategori:(1) Daerah permukiman kumuh di daerah lama;(2) Daerah permukiman kumuh di sekitar daerah industri;(3) Daerah permukiman kumuh di sepanjang sungai, rel kereta api dan jalan;(4) Daerah permukiman kumuh di sepanjang kotam/waduk;(5) Daerah permukiman kumuh di daerah pertanian;(6) Daerah permukiman kumuh di proyek perumahan. Muhtadi (1992), mengadakan penelitian untuk disertasi, yakni tentang peran serta warga Kota Jakarta dalam permasalahan Permukiman kumuh. Penelitian ini mengahasilkan identifikasi kumuh tidak hanya secar fisik saja tetapi juga meliputi kumuh sosial ekonomi, kumuh budaya dan juga kumuh politik. Dengan demikian penanganan daerah kumuh haruslah melibatkan peran serta masyarakat di dalamnya, bukan berdasarkan ukuran normatif orang yang berada.

Arap (1996), penelitian di daerah kumuh yang berlokasi di Keturahan Sangkrah, Kecamatan Pasar Kliwon Kota Surakarta, mengadakan penelitian pada permukiman kumuh dengan menggunakan pendekatan ekologi. Pendekatan ekologis 
dengan menggunakan beberapa parameter, yaitu komponen abiotik dengan parameter kualitas air dan tanah; komponen biotik dengan parameter burung, tumbuhan dan binatang; dan komponen social ekonomi dengan parameter tingkat pendapatan penduduk, tenaga kerja, tingkat pendi-dikan demografi, kesehatan dan fasilitas sosial.

Djaka (2001) mengadakan penelitian tentang perkembangan permukiman kumuh di kota yogyakarta tahun 19702000. Penelitian ini menggunakan foto udara multi temporal dengan jenis foto udara pankromatik hitam putih serta overlay dengan data terestrial . Hasil dari penelitian ini adalah terdeteksinya perkembangan permukiman kumuh selama tahun 1970 hingga tahun 2000.

\section{KESIMPULAN DAN SARAN}

1. Pemerintah Daerah Kota Surakarta harus berusaha untuk mengatasi permasalahan permukiman kumuh yang ada di Keca-matan Banjarsari sebagai bagian integral dari wilayahnya secara komprehensif. Penanganan masalah tidak hanya me-nyangkut penghentian atau penghilangan kawasan permukiman kumuh yang ada tetapi juga harus dikemanakan para penghuninya. Seperti halnya saran dari beberapa ahli permukiman, pendirian rumah - rumah susun bagi warga kurang mampu dengan kondisi layak pakai serta harga yang tidak mahal bisa ditempuh. Sudah saatnya wilayah Kecamatan Banjarsari mengalami pertumbuhan wilayah secara vertikal dan tidak harus selalu secara horizontal yang terus menerus menghabiskan lahan produktif yang masih tersisa.

2. Dalam hubungannya dengan penataan ruang kota, pembangunan permukiman - permukiman sehat yang dilakukan juga harus diimbangi dengan penyediaan lahan - lahan penyeimbang lingkungan seperti taman, jalur hijau ataupun hutan kota. Hal ini cukup penting terutama dalam mengurangi tingginya polusi lingkungan yang terjadi.

\section{DAFTAR PUSTAKA}

Arap, Matinguny Adris. 1996. Aplication of The Ecological Approach to Urban Problems and Solutions: Urban Ecosystems-Focusing on Slum Settlement Environment; Sangkrah Sub-County.Solo Municipality.Pasar Kliwon County.Central JavaProvince, Indonesia. Tesis; Post Graduate Studies Program Dept. Of Inter-Disciplinary Studies Gadjah Mada University Yogyakarta Indonesia.

Bintarto dan Surastopo Hadisumarno. 1979. Metode Analisa Geografi. Jakarta : LP3ES

Bintarto. 1977. Geografi Kota. Yogyakarta: Up Spring

Bintarto. 1983. Geografi Kota Dan Desa. Yogyakarta : Up Spring

Bintarto. 1984. Interaksi Desa Kota Dan Permasalahannya. Yogyakarta : Fakultas Geografi UGM

Budiharjo, Eko. 1984. Sejumlah Masalah Permukiman Kota. Bandung: Alumni 
Budisantoso, Sugiharto. 1996. Penginderaan Jauh. Diktat Kuliah. Surakarta: Fakultas Geografi UMS.

Clinord, Marshal, B. 1978. Slum and community development. Toronto - Ontario: CollierMacmillan Canada Ltd.

Dahroni dan Sugiharto Budisantoso. 1998. Geografi Permukiman I dan II. Diktat Kuliah. Surakarta : Fakultas Geografi UMS

Gilbert, Alan., dan Gugler, Josef. 1996. Urbanisasi dan Kemiskinan di Dunia Ketiga. Yogyakarta: Tiara Wacana.

Ida Bagoes Mantra. 1981. Pengantar Studi Demografi. Yogyakarta : Nurcahya

Kasto.1984. Geografi Pendudukan dan Permasalahan Kependudukan. Yogyakarta : Pusat Penelitian Kependudukan UGM

Laquian, Aprodicio, A. 1971. Slum are for People. Honolulu: East-west Centre Press.

Marwasta, Djaka 2001. Perkembangan Permukiman Kumuh di Kota Yogyakarta Tahun 1970-2000. Tesis. Program Pasca Sarjana Universitas Gadjah Mada Yogyakarta.

Marwasta, Djaka dan Kuswaji Dwi Priyono. Analisis karakteristik Permukiman Desa-desa Pesisir Di Kabupaten Kulonprogo. Forum Geografi, Vol. 21, No. 1 Juli 2007. Hlm 5768.

Muhtadi.W., Muhammad. 1992. "Peran Serta Warga Kota Jakarta dalam Permasalahan Permukiman Kumuh", Disertasi, Universitaas Gadjah Mada, Yogyakarta.

Schmidt dan Ferguson. 1951. Rainfall Types Based On Wet And Dry Periode Ration For Indonesia With Western New Guinea No. 42. Jakarta : Jawatan Meteorologi Dan Geofisika.

Sinaga, Maruli. 1995. Pemetaan Data Statistik. Yogyakarta: Fakultas geografi. Universitas Gadjah Mada

Singarimbun, Masri dan Soffian Effendi. 1981. Metode Penelitian Survai. Jakarta: LP3ES

Su Ritohardoyo dan Priyono. 2005. Perkembangan Permukiman dan Perubahan Daya Dukung Lingkungan Perdesaan Daerah aliran Sungai Progo. Jurnal Forum Geografi UMS, Vol. 19, No. 2 Desember 2005.

Su Ritohardoyo. 2007. Perubahan Permukiman Perdesaan Pesisir Kabupaten Gunung Kidul DIY Tahun 1996-2003. Forum Geografi. Vol.21, No.1, Desember 2007. Hlm 78-92.

Sudiharjo, Basuki. 1977. Prinsip Dasar Pembuatan Peta Tematik. Yogyakarta: Fakultas Geografi UGM

Sulistyono, Budi. 1983. Pemetaan Distribusi Dan Kepadatan Penduduk Di Daerah Kotamadya Surakarta Tahun 1982.Skripsi Sarjana.Yogyakarta: Fakultas Geografi. Universitas Gadjah Mada

Sumaatmadja, Nursid. 1981. Studi Geografi, Suatu Pendekatan Dan Analisa Keruangan. Bandung: Alumni.

Sumarwoto, Otto. 1983. Ekologi Lingkungan Hidup Dan Pembangunan. Jakarta: Penerbit Djambatan. 
Sutanto. 1985. Deteksi Kemiskinan di Kota Berdasarkan Foto Udara. Yogyakarta: Fakultas Geografi UGM - PUSPICS.

Wulandari, Nur M.T. 2003. Interpretasi Foto Udara dan Aplikasi SIG Untuk Kajian Agihan Daerah Permukiman Kumuh Di Kecamatan Banjarsari Kota Surakarta Tahun 2001. Skripsi Sarjana. Surakarta: Fakultas Geografi Universitas Muhammadiyah Surakarta

Yunus, Hadi Sabari. 2000. Struktur Tata Ruang Kota. Yogyakarta: Pustaka Pelajar Offset 


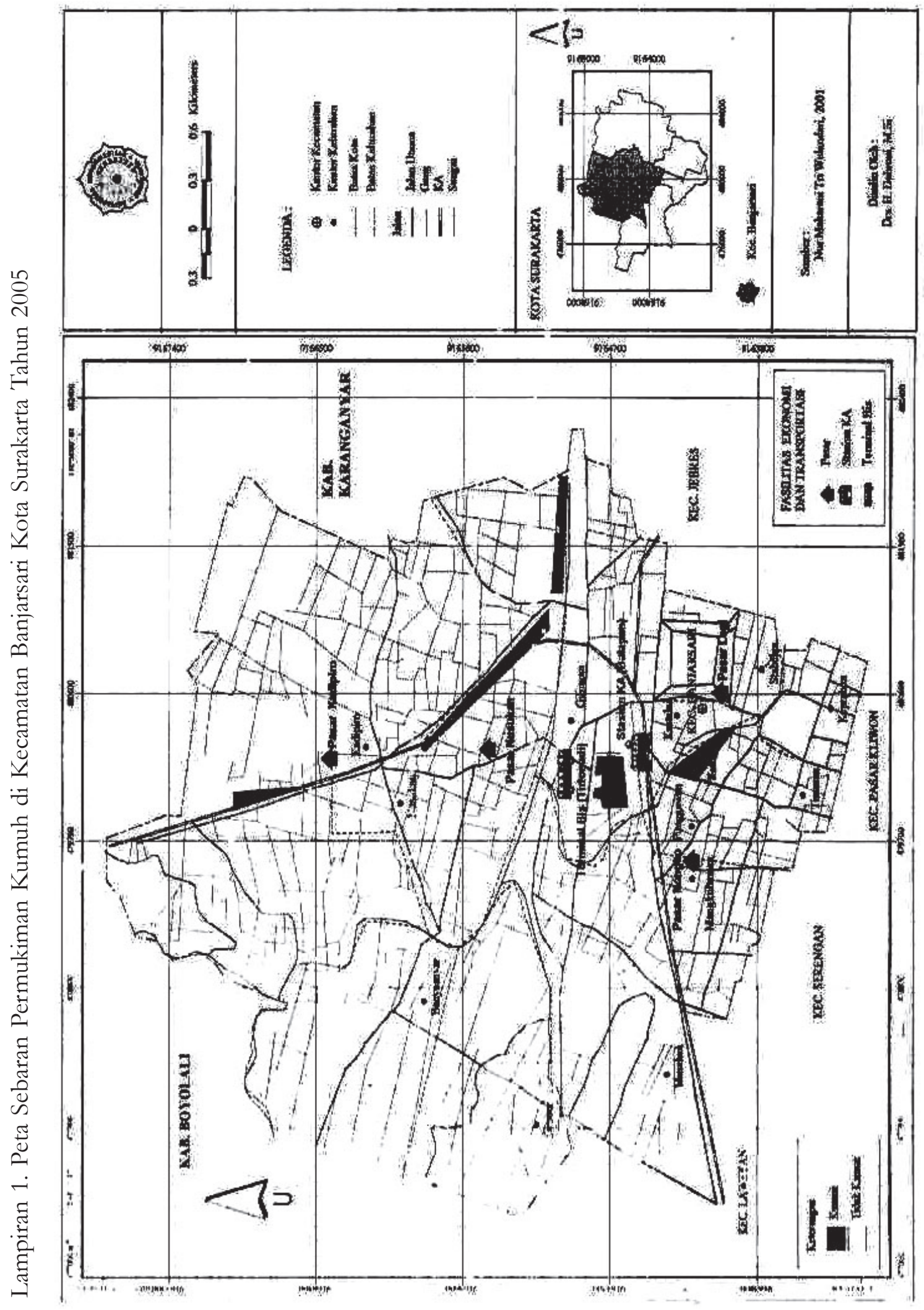




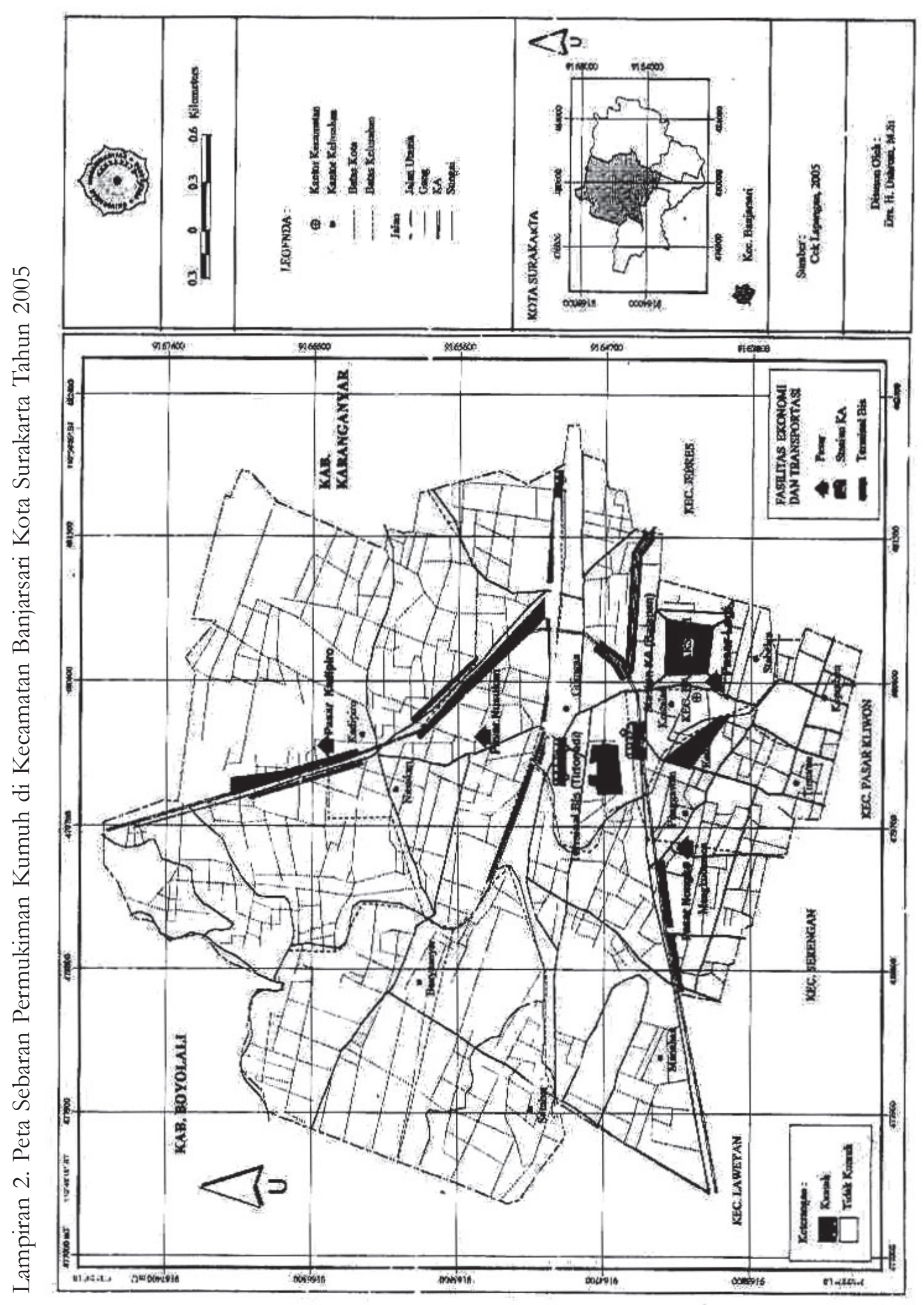

Analisis Keruangan terhadap Perubahan dan ... (Dahroni) 


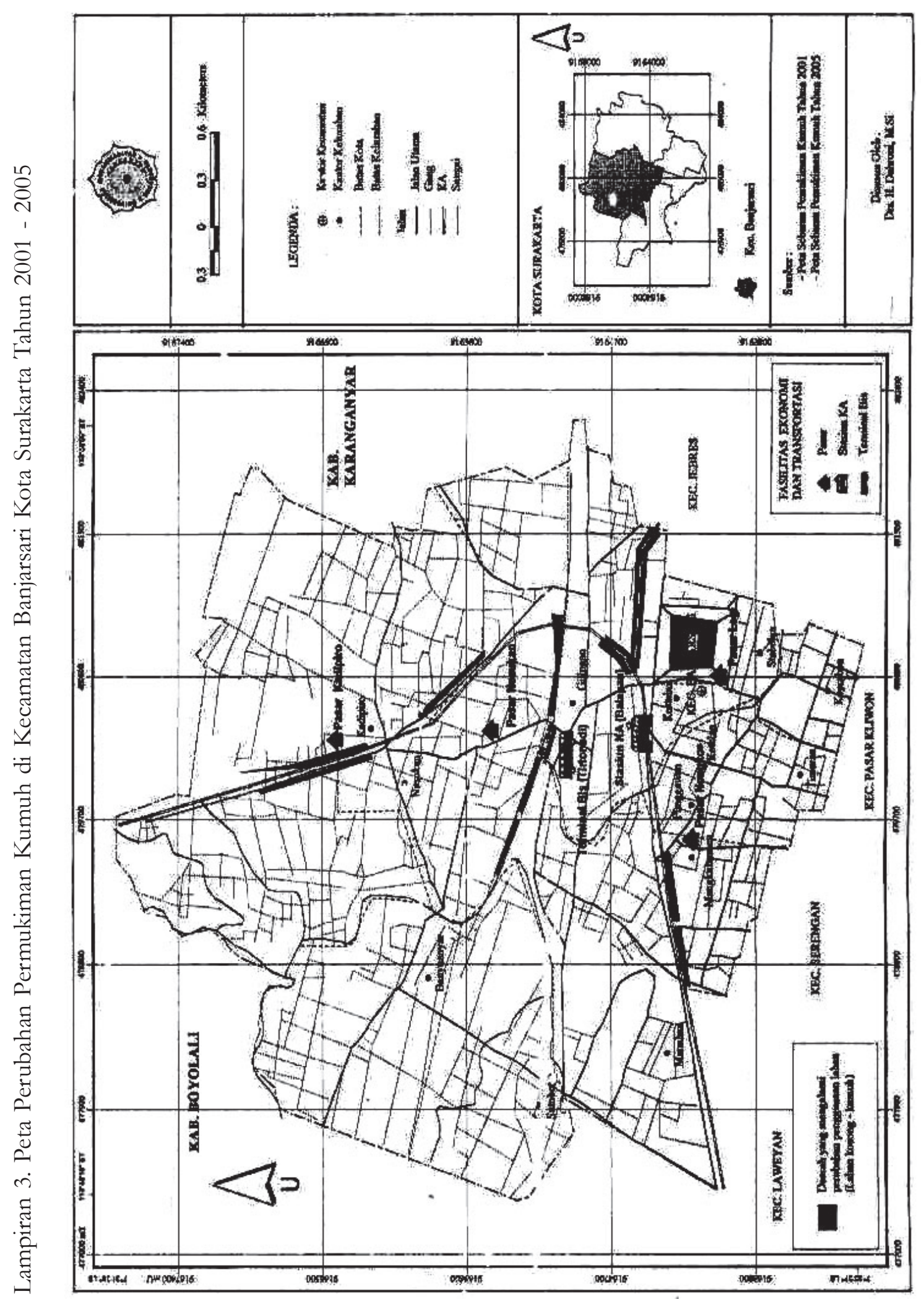

